податкової служби як складова етики державного службовця України : тези доп. наук.-практ. конф., Ірпінь, 15 груд. 2006 р. - Ірпінь, 2006. - С. 205-208. 8. Сисосва С. О. Інтерактивні технології навчання дорослих : [навч.-метод. посіб.] / С. О. Сисоєва. - К. : ВД «ЕКМО», 2011. - 320 с. 9. Цюман Т. П. Формування культури життєвого самовизначення старшокласників засобами освітнього тренінгу : дис. ... канд. пед. наук : 13.00.05/ Цюман Тетяна Петрівна. - К., 2008. - 221 с. 10. Шамрай В. О. Формування інформаційної культури фахівця податкової служби України [Електронний ресурс] / В. О. Шамрай, А. П. Кошіль, А. І. Жаров // Проблеми впровадження інформаційних систем і технології : тези доп. (V Міжнар. наук.-практ. конф., Ірпінь, 15-17 трав. 2004 р.).- Ірпінь, 2004.- Режим доступу : http://nc.nusta.com.ua/Kyrsi\%202004/tezi/images_tezi/041.htm. - Назва 3 екрана. 11. Шелестова Л. Інтерактивні технології: «за» i «проти» / Л. Шелестова // Шкільний світ. -2003 . - № 12. - С. 3.

УДК 371.134

Роман Горбатюк

\title{
ОСОБЛИВОСТІ ПІДГОТОВКИ МАЙБУТНІХ УЧИТЕЛІВ ТЕХНОЛОГІЙ ДО ПРОФЕСІЙНОЇ ДІЯЛЬНОСТІ В СУЧАСНИХ УМОВАХ
}

Горбатюк Р. М. Особливості підготовки майбутніх учителів технологій до професійної діяльності в сучасних умовах.

У статті зроблено спробу обгрунтувати особливості підготовки майбутніх учителів технологій до професійної діяльності на основі сучасних інформаційнокомунікаційних технологій. Навчальними планами i кваліфікаційною характеристикою на кожному етапі становлення педагогічних фахівців визначено комплекс психолого-педагогічних, суспільних, загальнотехнічних i спеціальних дисциплін, що у взаємозв'язку формують професійні вміння і навички, розвивають творче мислення студентів.

Ключові слова: вчитель технологій, інформаційно-комунікаційні технології, вміння, навички, підготовка, професійна діяльність.

Горбатюк Р. М. Особенности подготовки будущих учителей технологий в профессиональной деятельности в современных условиях.

В статье сделана попытка обосновать особенности подготовки будущих учителей технологий к профессиональной деятельности на основе современных информационно-коммуникационных технологий. Учебными планами и квалификационной характеристикой на каждом этапе становления педагогических специалистов определен комплекс психолого-педагогических, общественных, общетехнических и специальных дисциплин, которые во взаимосвязи формируют профессиональные умения и навыки, развивают творческое мышление студентов.

Ключевые слова: учитель технологий, информационно-коммуникационные технологии, умения, навыки, подготовка, профессиональная деятельность.

Horbatyuk R. M. The features of training the teachers the technology of professional activities under present circumstances.

This paper is an attempt to justify the features of training future technology teachers the professional activities based on modern information and communication technologies. Curriculum and qualification characteristics at each stage of educational experts are defined, 
a set of psychological, educational, social, general technical and special subjects that form the professional relationship skills and develop creative minds are presented. The course for training technology teachers is implemented, it discloses the special features of the specialty, refine knowledge by accepting the assimilation of information and communication technologies during the study of general and professionally oriented disciplines. The introduction of the educational process of modern information and communication technology using active forms and methods to create a predictive information environment is shown, that provides educational process being more interactive.

Key words: teaching technologies, information and communication technologies, skills, training, professional activity.

Соціально-економічні зміни в сучасному українському суспільстві висувають нові вимоги до якості підготовки фахівців, змісту їхньої педагогічної діяльності, яка впливає на формування професійних компетентностей.

Підготовка майбутніх учителів технологій в педагогічному вищому навчальному закладі $\epsilon$ складним процесом, кінцевою метою якого $\epsilon$ формування комплексу спеціальних знань, умінь і навичок, що забезпечують успішне виконання професійної діяльності. Тому актуальним завданням вищої освіти на сучасному етапі становлення суспільства є розвиток і використання новітніх досягнень науки, техніки і технології у створенні вдосконаленого матеріально-предметного середовища в житті та діяльності кожної людини не тільки на виробництві та побуті, а й у навчанні.

Різні аспекти професійної підготовки майбутніх учителів технології розглядались у працях багатьох науковців: А. Вихруща, Р. Гуревича, Й. Гушулея, О. Коберника, В. Мадзігона, Л. Оршанського, В. Сидоренка, Г. Терещука, Д. Тхоржевського та ін.

Водночас аналіз наявних робіт показав, що питання підготовки майбутніх учителів технології не знайшли належного відображення і вимагають додаткового вивчення. У представленому дослідженні ми розглянемо проблему підготовки майбутніх учителів технології до професійної діяльності на основі сучасних інформаційно-комунікаційних технологій (IКТ).

Метою статті є обгрунтування особливостей підготовки майбутніх учителів технології до професійної діяльності на основі сучасних інформаційнокомунікаційних технологій.

Основними особливостями формування кваліфікованих педагогічних кадрів $є$ оволодіння методологією психолого-педагогічної, профорієнтаційної, загальнотехнічної та спеціальної освіти. Навчальними планами і кваліфікаційною характеристикою на кожному етапі професійної підготовки визначено комплекс психолого-педагогічних, суспільних, загальнотехнічних і спеціальних дисциплін, що у взаємозв’язку формують професійні вміння і навички, розвивають творче мислення студентів і $є$ теоретико-практичною основою для подальшої підготовки майбутніх учителів технології.

3 урахуванням цілей i завдань підготовки майбутніх учителів технологій у Тернопільському національному педагогічному університеті імені Володимира Гнатюка (ТНПУ) ми орієнтувалися на дидактичний комплекс, на основі якого формувалися узагальнені професійні знання і вміння.

Дидактичний комплекс охоплює:

- типовий навчальний план і програми (навчальні, робочі);

- навчально-методичні посібники; 
- методичні вказівки для проведення лабораторних і практичних занять;

- систему методів, засобів і форм організації навчально-пізнавальної діяльності здійснення взаємозв'язку загальноосвітніх і професійно-орієнтованих дисциплін;

- електронні навчально-методичні комплекси, які містять лекції, алгоритми проведення лабораторно-практичних занять, тестові завдання для поточного та підсумкового контролю, завдання для індивідуальної і самостійної роботи, перелік питань для самопідготовки і самоконтролю тощо [1].

Проведені нами дослідження надали підстави стверджувати, що перераховані можливості дидактичного комплексу забезпечують формування вмінь інтегрувати навчальний матеріал; перенесення знань і вмінь 3 одного предмета на інший; усунення дублювання (повторення) деяких тем навчального матеріалу; підвищення інтересу студентів до матеріалу, що вивчається; узагальнення й систематизацію розрізнених знань, отриманих під час вивчення суміжних предметів.

У ТНПУ на інженерно-педагогічному факультеті здійснюється такий напрям підготовки майбутніх учителів технології, який дозволяє поряд із розкриттям загальної специфіки спеціальності поступово конкретизувати та деталізувати знання шляхом засвоєння IКТ під час вивчення загальноосвітніх і професійно-орієнтованих дисциплін. Отже, предмети, що викладаються на інженерно-педагогічному факультеті, доповнюють і значно розширюють світогляд студентів у тій галузі професійної діяльності, де поєднуються педагогічні та інженерно-технічні принципи й закономірності.

Нині навчання в педагогічному вищому навчальному закладі неможливе без оволодіння навичками використання інформаційно-комунікаційних технологій, зокрема комп'ютерних. Склалися такі умови, коли студент у стінах ВНЗ повинен навчитися бачити можливі варіанти використання засобів комп'ютерних технологій у своїй професійній діяльності. Навчитися такому «баченню»- справа складна і вимагає належної підготовки професорсько-викладацького складу, сучасного технічного і програмного забезпечення. У цьому напрямі передбачено вивчення низки дисциплін, які тісно пов'язані одна 3 одною та сформовані так, щоб допомогти студентам у навчальному процесі.

Упровадження в навчально-виховний процес сучасних IКТ з використанням активних форм і методів навчання (ігрові технології; проблемне навчання; технологія розвивального навчання; технологія програмованого навчання; комп'ютерні технології навчання; технологія модульного навчання; технологія активізації творчої діяльності суб'єктів навчання тощо) дозволяє створити інтелектуальне інформаційне середовище, яке надає освітньому процесу університету більшої інтерактивності $[2 ; 3 ; 4]$.

Інтенсивне зростання обсягів проектно-конструкторських робіт, складність побудови графічних об'єктів, підвищення якості і зменшення термінів виконання графічних побудов й іншої технічної документації $\epsilon$ важливим й актуальним завданням упровадження в навчальний процес підготовки вчителів технології елементів системи автоматизованого проектування (САПР).

Досягнення цієї мети можливе за таких умов:

- систематизації i вдосконалення проектування навчального i виробничого процесів на основі ІКТ;

- підвищення якості управління процесами графічного моделювання;

- використання методів багатоваріантного проектування й оптимізації;

- створення банку даних задля підвищення ефективності побудови об'єктів і 
зменшення тривалості процесу на їх створення;

- уніфікації і стандартизації методів графічного моделювання (проектування).

Одним із основних складників САПР є комп'ютерна графіка, що визначається сукупністю технічних, програмних i мовних засобів зв'язку студента 3 комп'ютерними засобами на рівні зорового сприйняття під час виконання геометричних побудов та розв'язання різних завдань. Головним завданням комп'ютерної графіки є не тільки зображення окремих об'єктів, а також їх конструювання та вибір оптимального варіанта 3 наперед заданими критеріями, що неможливо під час використання звичайного (ручного) моделювання. Використовуючи універсальні пакети прикладних програм (ППП) можна створювати, зберігати й обробляти моделі та їх зображення за допомогою комп'ютерної техніки.

Розуміння наочних методів створення об'ємних тіл формує в майбутніх учителів технології базові знання про ефективні способи моделювання, які дозволяють створювати моделі складних за формою деталей і конструкцій.

Одним із напрямів підвищення рівня ефективності навчання професійноорієнтованих дисциплін $є$ педагогічно вивірене використання ІКТ під час підготовки студентів у поєднанні з системою психологічних і педагогічних засобів активізації навчальної діяльності. Застосування комп'ютерних засобів передбачає опанування майбутніми вчителями технологій психолого-педагогічними знаннями, навичками використання методів навчання, прикладного програмного забезпечення, тобто використання сучасних ІКТ забезпечує навчальний заклад. Це надає змогу під час вивчення теоретичного матеріалу звернути основну увагу студентів на 3'ясування суті досліджуваних явищ, побудову імітаційних моделей, інтерпретацію результатів, отриманих за допомогою комп'ютера, зекономити час на побудову графічних зображень тощо [5].

Сучасні тенденції проектування машин і систем свідчать про те, що задля досягнення успіху майбутній учитель технологій повинен однаково добре орієнтуватися в самому об'єкті, процесі, системі проектування; апараті оброблення й аналізу вхідної і вихідної інформації про об'єкт, процес, систему, зовнішнє середовище; у математичному моделюванні, тобто в постановці та формалізації завдання, яке полягає в умінні переробити технічне завдання з проблемно-змістового на мову математичних схем і моделей і далі - в спеціальне програмне забезпечення; у методах пошуку оптимального рішення; у відповідному програмному забезпеченні систем автоматизованого проектування (діалогових системах, банках даних, базах знань тощо); у вільному володінні засобами обчислювальної техніки [6].

Оскільки вивчення предметної галузі майбутніми вчителями технологій формує в них практичні компетентності, то відбувається певне виконання студентами ролі інженера. Це дозволяє не тільки значно інтенсифікувати навчальний процес, а й підвищити теоретичний рівень і практичну значущість результатів навчання в педагогічному університеті. Крім цього, одержання знань 3 предметної галузі методами інженерії, є не тільки ефективним, а й має на меті їх використання задля одержання професійних знань підготовки фахівців технології в різних галузях.

Згідно 3 чинними навчальними планами напряму підготовки «Технологічна освіта» передбачено вивчення навчальної дисципліни «Комп'ютерна графіка». Цей предмет передбачає ознайомлення студентів 3 графічним редактором КОМПАС (комп'ютерні автоматизовані системи).

Вивчення дисципліни базується на знаннях шкільних курсів математики, трудового навчання i креслення, що сприяє успішному засвоєнню професійно- 
орієнтованих дисциплін навчальних планів інженерно-педагогічного факультету. Це має виняткове значення в підготовці майбутніх учителів технологій до практичної роботи у школі.

На рисунку 1 представлено модель підготовки майбутніх учителів технології на основі сучасних інформаційних технології.

Суттєвим чинником розроблення моделі $€$ врахування чинних нормативних документів щодо технологічної освіти. Це забезпечує відбір і структурування змісту навчального матеріалу професійної підготовки вчителя технологій, проектування модульних програм загальноосвітніх і професійно-орієнтованих дисциплін відповідно до навчальних планів усіх освітньо-кваліфікаційних рівнів і розроблення методичного супроводу.

Вагоме значення у становленні професіоналізму студентів мають дисципліни, які забезпечують формування професійних компетентностей студентів, зокрема інформаційних. Тому навчальні плани підготовки майбутніх учителів технологій передбачають вивчення низки предметів, спрямованих на забезпечення їх інформаційної готовності, а саме: «Освітні технології навчання», «ІТЗН», «Комп’ютерна графіка», «Комп’ютерні інформаційні технології в освіті, науці» тощо.

3 огляду на це в педагогічній професійній діяльності майбутніх учителів технологій комп'ютерні засоби використовуються як інструмент здійснення проектувальної, технологічної, організаційно-управлінської та науково-дослідної діяльності, а також як засіб навчання.

Незважаючи на значні досягнення в цьому напрямі, комп'ютерна підготовка студентів потребує докорінного перегляду, виходячи з сучасних вимог освіти. У першу чергу студенти повинні одержати знання комп'ютерної грамотності на рівні користувачів персональних комп'ютерів (ПК). Програма навчання повинна бути обов'язковою для всіх студентів, починатися 3 першого курсу і передбачати вивчення будови комп'ютера, операційних систем і оболонок (Norton Comander, Windows тощо). Подальше формування комп'ютерної грамотності повинно передбачати застосування в навчальному процесі підготовки майбутніх учителів технологій прикладних навчальних програм різного спрямування.

Підготовка майбутніх учителів технології 3 уведенням інформаційнокомунікаційних технологій не повинна обмежуватись вивченням тільки однієї конкретної дисципліни. Так, у процесі вивчення таких предметів, як «Технічна механіка», «Деталі машин», «Автоматизоване проектування в машинобудуванні» тощо, можна використовувати пакет програмного забезпечення WinMachin, редактор для математичних розрахунків МathCAD, середовище візуального моделювання MathLAB, які дозволяють описувати обчислювальний алгоритм у загальноприйнятих математичних виразах (обчислювати лінійні, квадратні рівняння, системи рівнянь, обчислювати інтеграли, матриці, знаходити похідні, будувати дво- і тривимірні графіки залежностей тощо) й одержувати результати лабораторних обчислень.

Поєднуючи пакети прикладного навчального програмного забезпечення, можна створити у студентів цілісне уявлення про можливості комп'ютера як засобу автоматизації навчального процесу. Студенти повинні використовувати ПК не тільки в навчальному процесі, а також у науковій діяльності- для написання курсових, магістерських і дипломних робіт тощо. 


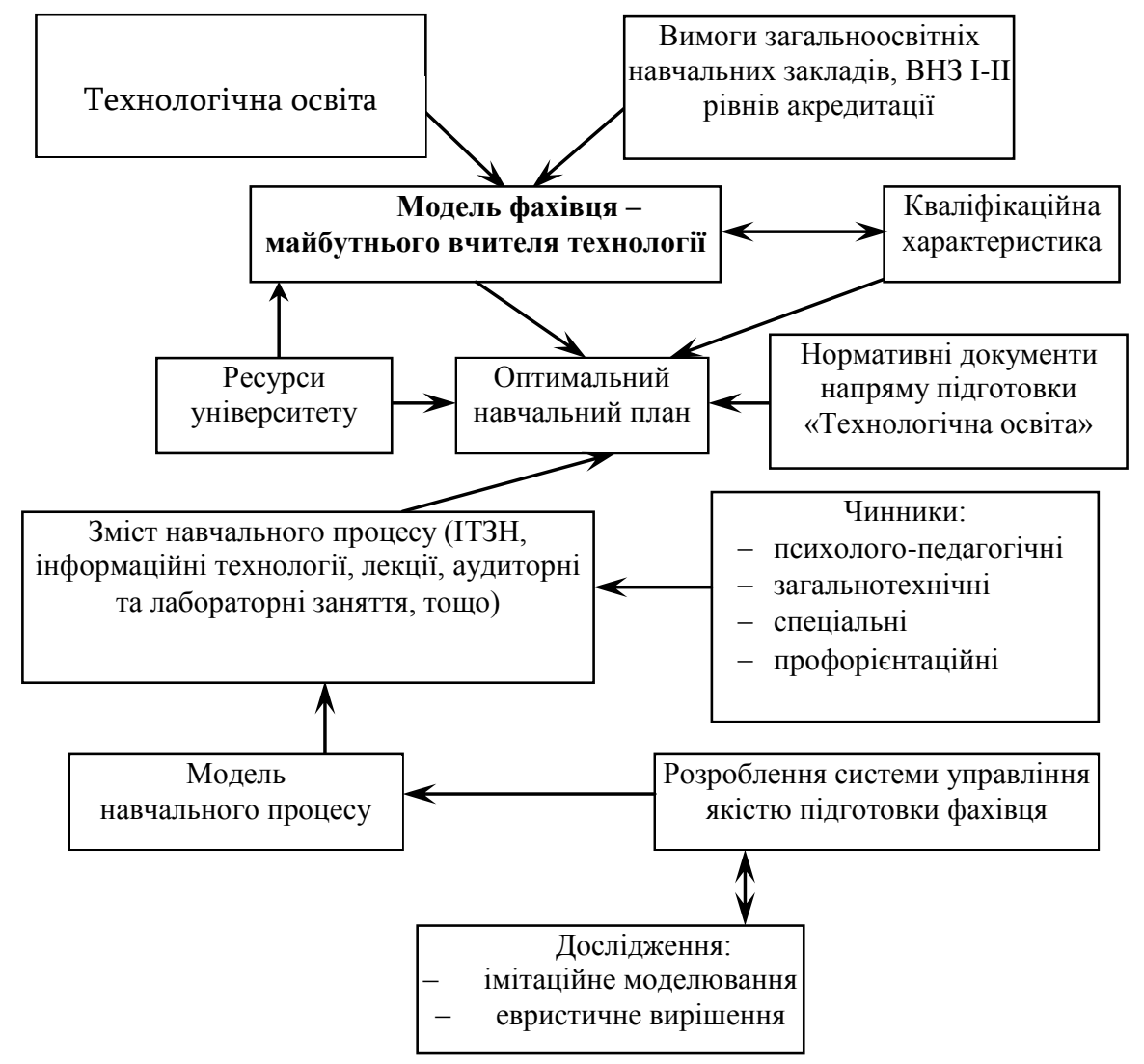

Рис. 1. Модель підготовки майбутніх учителів технологій до професійної діяльності

Застосування комп'ютерних засобів підвищує пізнавальний інтерес майбутніх фахівців до навчального матеріалу, розширює можливості цілеспрямованого впорядкованого формування, поглиблення та розширення теоретичних знань студентів, робить процес навчання технологічнішим $\mathrm{i}$ результативнішим. Застосування комп'ютерних технологій у навчальному процесі надає змогу систематично розглядати різні способи побудови моделей, виробничих i технологічних процесів, збільшити їх кількість, урізноманітнити зміст, розширити можливості узагальнення комп'ютерних понять. Зазначимо, що використання прикладного програмного забезпечення дозволяє викладачу повною мірою реалізувати такі загальнодидактичні принципи навчання, як: свідоме виконання навчальних завдань, наочність, доступність, послідовність, диференціацію та індивідуалізацію навчального процесу.

Незалежно від конкретної структури комп'ютерних дисциплін на різних рівнях їх вивчення (ПТУ, ВПУ, коледж, вища школа тощо) необхідно забезпечити наступність засвоєння майбутніми фахівцями основних ідей сучасних САПР на складнішому 
навчальному матеріалі. Передусім ідеться про ідеї елементарності, принципи збереження, симетрії. Посилення тенденцій до інтеграції в сучасному суспільстві висуває на чільне місце ідею єдності наукової картини світу, де комп'ютерні вміння відіграють провідну роль.

3 огляду на це використання ІКТ у навчальному процесі надає змогу педагогу під час занять акцентувати увагу на стимулюванні процесів саморозвитку, самореалізації й самоосвіти студентів. Ефективність заняття підвищується тоді, коли студенти повністю залучені до роботи. Цього можна досягти лише за умови розумного використання IKT.

На основі аналізу програм (навчальних, робочих), кваліфікаційних характеристик, навчальних планів i представленої моделі підготовки вчителя технологій можна стверджувати, що сучасна система навчання потребує докорінного перегляду. Такі зміни повинні бути спрямовані на досягнення однієї мети підготувати інтелектуального фахівця, який відповідає сучасним вимогам. Тому якість підготовки кваліфікованих спеціалістів є тією передумовою, яка має суттєвий уплив на подальший розвиток народної освіти в державі.

Перспективами подальших розвідок $\epsilon$ розроблення системи підготовки майбутніх учителів технологій до професійної діяльності 3 урахуванням сучасних тенденцій розвитку суспільства.

\section{Література}

1. Горбатюк Р. М. Проблеми автоматизації освітнього процесу / Р. М. Горбатюк // Проблеми педагогічних технологій : зб. наук. праць Волинського держ. ун-ту ім. Лесі Українки. - Луцьк, 2006. - Вип. 2-4 (31-33). - С. 356-362. 2. Горбатюк Р. М. Формування комп'ютерної культури в майбутніх інженерів-педагогів на основі інтеграції психологопедагогічної і фахової підготовки / Р. М. Горбатюк// Наукові записки Тернопільського нац. пед. ун-ту ім. В. Гнатюка. Серія : Педагогіка. - Тернопіль, 2009. - № 1. - С. 157-163. 3. Романишина Л. М. Інноваційні технології в підготовці майбутніх фахівців/ Л. М. Романишина, О. Я. Романишина // Збірник наукових праць Кременецького обл. гуманітар. пед. ін.-ту ім. Т. Шевченка. Серія : Педагогічні науки. - Кременець, 2007. Вип. 2. - С. 50-57. 4. Романишина Л. М. Сучасні педагогічні технології підготовки майбутніх фахівців / Л. М. Романишина // Проблеми освіти; спец. випуск. - К. : Вид-во наук.-метод. центру вищої освіти, 2006. - С. 140-147. 5. Шеннон Г. Р. Имитационное моделирование систем - искусство и наука: [пер. с англ.] / Г.Р.Шеннон; под ред. Е. К. Масловского. - М. : Мир, 1978. - 418 с. б. Веселовська Г. В. Основи комп'ютерної графіки : [навч. посіб.] / Г. В. Веселовська. - К. : Центр навч. літ-ри, 2004. 392 c.

\section{НАЙВАЖЛИВІШ АСПЕКТИ МОВНОЇ ПІДГОТОВКИ СТУДЕНТІВ ЛІСОТЕХНІЧНОГО НАПРЯМУ НАВЧАННЯ}

Гриджук О. С. Найважливіші аспекти мовної підготовки студентів лісотехнічного напряму навчання.

У статті обгрунтовано доцільність поглиблення мовної підготовки студентів лісотехнічного ВН3; окреслено основні аспекти цього процесу (термінологічний, лексикографічний, граматико-стилістичний, фахово-прикладний); визначено способи опрацювання термінологічної лексики лісівництва та деревообробки. 